\title{
ANALISIS PENGEMBANGAN OBJEK WISATA ASAM SATU BEACH KABUPATEN FLORES TIMUR NUSA TENGGARA TIMUR
}

\author{
${ }^{1)}$ Fransiskus Laga Payong ${ }^{2)}$ Restu Wardani \\ Universitas Kanjuruhan Malang \\ Email: 1)engky13payong@gmail.com²nilarestu@unikama.ac.id
}

\begin{abstract}
Abstrak
Asam Satu Beach merupakan salah satu pantai di Larantuka, berada di ujung timur Pulau Flores yang terletak di Kelurahan Weri Kecamatan Larantuka Kabupaten Flores Timur. Pantai ini berada di pusat kota. Asam Satu Beach memiliki daya tarik wisata berupa sunset. Tujuan penelitian ini adalah untuk mengetahui bagaimana pengembangan wisata yang telah dilakukan oleh pengelola objek wisata Asam Satu Beach. Jenis penelitian yang digunakan adalah penelitian deskriptif dengan pendekatan kualitatif. Peneliti hadir selama penelitian berlangsung untuk mengumpulkan data baik data primer maupun data sekunder. Pengumpulan data dilakukan dengan 3 teknik yaitu: wawancara, observasi, dan dokumentasi. Analisis datanya dengan analisis deskriptif kualitatif dan analisis SWOT. Berdasarkan hasil penelitian dan analisis yang dilakukan tentang pegembangan Objek Wisata Asam Satu Beach berdasarkan analisi SWOT sebagai berikut: Sampai saat ini Pantai Asam Satu Beach meliliki keindahan alam pantai yang masih alami, lokasi yang strategis, aksesbilitas yang dilalui jalan arteri, dan memiliki daya tarik tambahan seperti spot foto. Selain itu Pantai Asam Satu Beach memiliki beberapa kelemahan diantaranya, kurangnya promosi dan pungutan biaya masuk, kurangnya sarana dan prasarana seperti kamar ganti semua ini juga dikarenakan tanpa campur tangan pemerintah dalam mengolahnya. Pantai Asam Satu Beach yang merupakan wisata populer di Kota Larantuka, memberikan dampak posostif bagi masyarakat sekitar karena dapat menunjang lapangan pekerjaan dan menurunkan tingkat pengangguran.
\end{abstract}

Kata Kunci: Pengembangan Pariwisata, Asam Satu Beach

\section{PENDAHULUAN}

Asam Satu Beach merupakan salah satu pantai di Larantuka, berada di ujung timur Pulau Flores yang terletak di Kelurahan Weri Kecamatan Larantuka Kabupaten Flores Timur. Asam Satu Beach juga merupakan salah satu lokasi wisata di pusat kota selain Pantai Mercusuar Sarotari, Pantai Meting Doeng dan beberapa wisata lain di kota Larantuka. Meski berada di pusat kota, Asam Satu Beach cukup bersih dengan hamparan pasir putih kekuningan yang indah dengan adanya berbagai spot foto menarik yang kekinian sehingga tidak heran jika setiap sore pantai ini menjadi lokasi wisata yang sangat fotogenik untuk menikmati sunset.
Asam Satu Beach secara Geografis berbatasan dengan Pantai Meting Doeng bagian timur, bagian barat berbatasan dengan Pantai Gege, bagian utara berbatasn dengan Gor Weri, dan bagian selatan berbatasan dengan Pulau Adonara. Asam Satu Beach memiliki topografi bergelombang atau berkontur dengan kemiringan di atas $15 \%$. Curah hujan berkisar 1.321-2.320 mm/tahun. Suhu udara $23,5^{\circ}-24^{\circ}$ Celcius dengan suhu minimum terjadi pada bulan JuliAgustus.

Asam Satu Beach adalah wisata baru di Kota Larantuka memang terkenal dengan keindahan karena keasriannya di kembangkan masyarakat setempat 
sebagai objek wisata karena kondisi alam yang mendukung. Salah satunya yaitu keindahan Pantai yang masih alami. Pasir yang dimiliki berwarna putih kekuningan yang menunjukan bahwa Asam Satu Beach merupakan salah satu bentuk pengakatan dasar samudra.

Walaupun Pantai ini terbilang baru, tetapi mempunyai pengunjung yang cukup banyak ketika ada perayaanperaayaan besar seperti perayaan Semana Santa kebanyakan pengujung datang saat pagi dan sore hari. Wisatawan yang berkunjung di Asam Satu Beach adalah wisatawan lokal, dan tidak banyak juga wisatawan asing yang berkunjung ke pantai ini sekedar untuk menikmati keindahan pantai ataupun berfoto. Masyarakat setempat sudah membangun beberpa tempat yang dijadikan homestay dan areal parkiran serta membangun lopo-lopo atau pondok dengan barbagai macam ukuran yang dibangun menghadap ke laut di sekitar pantai tersebut. Dengan adanya pariwisata tersebut membawa dampak positif kepada masyarakat setempat, seperti adanya pembangunan rumah makan, ruangan ganti, kamar mandi, dan kios-kios yang yang mendukung perekonomian masyarakat setempat.

\section{METODE PENELITIAN}

Jenis penelitian yang digunakan dalam penelitian ini adalah penelitian deskriptif dengan pendekatan kualitatif. Disini penulis meganalisis atau menjelaskan Pengembangan Objek Wisata Asam Satu Beach di Kabupaten Flores Timur Nusa Tenggara Timur.

Berdasarkan sumbernya, data dibedakan menjadi dua, yaitu data primer dan data sekunder. Data primer diperoleh dari hasil observasi di lapangan dan wawancara dengan pengelola objek wisata dan pengunjung. Data sekunder diperoleh dari data-data penunjang yang tersimpan di instansi dinas pariwisata dan pengelola objek wisata.

Analisis data dengan SWOT dilakukan melalui metode perencanaan strategis yang digunakan untuk mengevaluasi kekuatan (strengths), kelemahan (weaknesses), peluang (opportunities), dan ancaman (threats) dalam suatu kegiatan pembangunan atau suatu bisnis (Muta'ali, 2015). Proses ini melibatkan penentuan tujuan yang spesifik dari spekulasi bisnis atau proyek dan mengidentifikasi faktor internal dan eksternal yang mendukung dan yang tidak mendukung dalam mencapai tujuan pengembangan objek wisata Asam Satu Beach.

\section{HASIL DAN PEMBAHASAN}

Hasil analisis dengan menggunakan analisis SWOT

\section{Kekuatan (Strenght)}

a. Objek Wisata Pantai yang Masih Alami

Pantai adalah sebuah bentuk geografis yang terdiri dari pasir dan terdapat di daerah pesisir laut. Daerah pantai menjadi batas antara daratan dan perairan laut. Pantai merupakan daerah yang luasnya dimulai dari daerah pesisir sampai jauh ke daratan.

Asam Satu Beach yang merupakan objek wisata baru di Kota Larantuka mempunyai keindahan alam pantai yang masih alami. Pantai yang masih alami adalah pantai yang masih terjaga kealamiahnya belum tersentuh dan tercemar oleh tingkah manusia keindahan alam Pantai ini menjadi daya tarik wisata tersendiri.

b. Keindahan Pantai Berupa Pasir Putih Kekuningan 
Asam Satu Beach merupakan pantai yang sangat dinikmati dan dikunjungi oleh wisatawan sekarang ini di Kota Larantuka, banyak pengunjung beramai-ramai datang untuk menikmati suasana pantai dan menghabiskan akhir pekan mereka.

c. Memiliki Posisi Stratrgis Dalam Kota

Posisi atau letak yang strategis adalah suatu sistuasi atau keadaan yang pas, tepat dan baik untuk mencapai tujuan tertentu.

d. Aksesbilitas Yang Dilalui Jalan Arteri

Pentingnya aksesbilitas dalam suatu daerah untuk mempermudah suatu aktifitas dan kegiatan dalam mencapai sesuatu. Aksesbilitas sangat diutamakan dalam bidang keparawisataan agar wisata mudah dijumpai dan peningkatan pengunjung. Asam Satu Beach adalah salah satu contoh wisata yang mempunyai lokasi yang sangat strategis dan bisa melalui jalan arteri.

\section{Kelemahan (Weakness)}

a. Kurangnya Promosi

Wisata Asam Satu Beach adalah salah satu wisata yang kurang diberi pengenalan atau promosi kepada masyarakat luas, karena promisi akan menunjang daya tarik pengunjung untuk berkunjung ke wisata Asam Satu Beach.

b. Kurangnya Sarana dan Prasarana Penunjang Wisata

Wisata yang baik adalah wisata menyediakan segala fasilitas untuk keperluan pengunjung ataupun memperindah wisata itu sendri. Semua sarana dan prasarana seperti kamar ganti untuk wisata Pantai seharusnya diperbanyak dan jangan sampai kurang. Asam Satu Beach yang merupakan wisata baru di Kota Larantuka saat ini, masih kurang dalam hal sarana dan prasana seperti tempat ibadah, tempat bermain untuk anak-anak dan kamar ganti.

c. Pengunjung Memadai Pantai di Hari Libur

Hari libur atau weekend dijadikan masyarakat sebagai hari untuk berlibur bersama keluarga atau teman-teman. Masyarakat memilih mengunjungi objek-objek wisata salah satunya Asam Satu Beach, hal ini dapat meningkatkan jumlah pengunjug dan pada hari biasa wisatawan yang berkunjung sangat sedikit.

d. Partisipasi Pemerintah dalam Pengelolaan Asam Satu Beach

Asam Satu Beach dikembangkan oleh muda-mudi di Kelurahan Weri dan masyarakat sekitar Kelurahan Weri tanpa adanya campur tangan atau partisipasi pemerintah dalam pengolahan objek wisata Asam Satu Beach. Keseluruhan pengembangan wisata ini adalah oleh masyarakat setempat. Di dalam pengembangan pariwisata harus adanya pengembangan yang berencana secara menyeluruh, sehingga dapat diperoleh manfaat yang optimal bagi masyarakat, baik dari segi ekonomi, sosial dan kultural. Perencanaan tersebut harus mengintegrasikan pengembangan pariwisata kedalam suatu program pembangunan ekonomi, fisik, dan sosial dari suatu negara. Di samping itu, rencana tersebut harus mampu memberikan kerangka kerja kebijakan pemerintah, untuk mendorong dan mengendalikan pengembangan pariwisata.

\section{Peluang (Opportunity)}

a. Meningkatkan Tenaga Kerja Dengan adnaya wisata Asam Satu Beach, dapat meyerap tenaga kerja dan meningkatkan pendapatan 
masyarakat sekitar objek wisata ini. Sehingga dapat mengurangi angka pengangguran di Kelurahan Weri. Secara praktis, tenaga kerja terdiri atas dua hal, yaitu angkatan kerja dan bukan angkatan kerja. Angkatan kerja (labour force) terditi atas golongan yang bekerja dan golongan penganggur atau sedang mencari kerja kelompok yang bukan angkatan kerja terdiri atas golongan yang bersekolah, golongan yang mengurus rumah tangga, dan golonganlain lain.

b. Objek Wisata Semakin Diminati dan Berkembang

Objek wisata semakin berkembang dan diminati karena Asam Satu Beach menyediakan fasilitas tambahan seperti spot-spot foto, rumah panggung, kebersihan pantai yang terjaga dan letak atau lokasi yang strategis.

c. Meningkatnya Perekonomian Masyarakat

Asam Satu Beach berpengaruh bagi perkembangan ekonomi masyarakat Kelurahan Weri, karena masyarakat setempat bisa mencari peluang kerja di daerah objek wisata Pantai. Dengan ini masyarakat akan mengalami peningkatan dalam segi perekonomian. Menurut Sukimo (1985), pengertian pertumbuhan ekonomi adalah perubahan tingkat kegiatan ekonomi yang berlaku dari tahun ke tahun. Untuk mengetahui pertumbuhan ekonomi, maka harus dilakukan perbandingan pendapatan nasional negara dari tahun ke tahun, yang kita kenal dengan laju pertumbuhan ekonomi.

d. Kemajuan Teknologi dan Media Cetak Upaya Peningkatkan Promosi Wisata.

Teknologi adalah keseluruhan sarana untuk menyediakan barang-barang yang diperlukan bagi kelangsungan dan kenyamanan hidup manusia.
Proses yang berjalan tersebut dapat menggunakan atau menghasilkan produk tertentu, dimana produk yang dihasilkan tidak terpisah dari produk lain yang telah ada. Lebih lanjut disebutkan pula bahwa teknologi merupakan suatu bagian dari sebuah integral yang terdapat di dalam suatu sistem tertentu.

\section{Ancaman (Threats)}

a. Persaingan Objek Wisata Lain.

Dengan adanya objek wisata Asama Satu Beach ini, akan meningkatkan jumlah wisatawan atau pengunjung yang akan berkunjung. Dengan berbagai kelebihan yang ada di wisata Asam Satu Beach akan menyebabkan wisata lain kurang pengunjung atau menyebabkan persaingan antara objek wisata. Saat adanya atau meningkatkan jumlah objek wisata maka pengelola harus semakin memeperindah tampilan wisata tersebut agar teteap menjadi poluler di masyarakat.

b. Penggunaan Fasilitas yang Tidak Terawat.

Semakin banyak pengunjung wisata maka semakin besar pula peluang untuk tidak menjaga fasilitas atau sarana yang ada di sekitar objek wisata. Oleh karna itu pentingnya ditanamkan kepada masyarakat tentang bagaimana menjaga segala fasilitas dengan mengadakan penyuluhan kepada masyarakat setempat atau kepada pengunjung.

\section{KESIMPULAN DAN SARAN}

\section{Kesimpulan}

Berdasarkan hasil penelitian dan analisis yang di lakukan tentang pegembangan Objek Wisata Asam Satu Beach berdasarkan analisis SWOT Sebagai berikut Sampai saat ini Pantai 
Asam Satu Beach meliliki keindahan lalam pantai yang masih alami, lokasi yang strategis, aksesbilitas yang dilalui jalan arteri, dan memiliki daya tarik tambahan seperti spot foto. Selain itu Pantai Asam Satu Beach memiliki beberapa kelemahan diantranya, kurangnya promosi dan pungutan biaya masuk, kurangnya sarana dan prasarana seperti kamar ganti semua ini juga dikarenakan tanpa campur tangan pemerintah dalam mengolahnya. Pantai Asam Satu Beach yang merupakan wisata populer di Kota Larantuka, memberikan dampak posostif bagi masyarakat sekitar karena dapat menunjang lapangan pekerjaan dan menurunkan tingkat pengangguran.

\section{Saran}

1. Bagi Pemerintah

a) Pemerintah harus mengambil bagian dalam pengembangan objek wisata Pantai Asam Satu Beach.

b) Pemerintah harus membantu pengelola dalam mengelola objek wisata Pantai Asam Satu Beach.

c) Pemerintah membantu mempromosikan wisata Pantai Asam Satu Beach.

d) Memberika fasilitas tambahan untuk menunjang objek Wisata Pantai

e) Bersama dengan pengelola pantai harus menetapakan tiket masuk Wisata.

f) Pemerintah wajib memnyiapkan keamanan demi kenyamanan pengujung.

2. Bagi Pengelola

a) Memperluas daerah parkir.

b) Membangun spot-spot foto lainnya.

c) Menyediakan tempat sampah di sekitar kawasan Pantai.

d) Membangun beberapa tempat yang dibutuhkan seperti, kamar ganti, tempat bermain, toilet, tempat ibdah.
3. Bagi pengunjung

a) Menjaga kebersihan sekitar objek wisata pantai Asam Satu Beach.

b) Menjaga fasilitas yang ada di sekitar kawasan pantai.

c) Memberikan bantuan berupa dana untuk memembantu pengembangan wisata.

\section{DAFTAR RUJUKAN}

Anonim, 2009. Analisis SWOT. http://id.wikipedia.org/wiki/Ana lisis_SWOT.Diakses Senin 05 Februari 2018.

Agung Respati. 2001. "Pengaruh Pengembangan Pariwisata Terhadap Lingkungan Sosial Ekonomi Sekitar Obyek Wisata Alam Grojogan Sewu Tawangmangu Karanganyar Surakarta". Tesis. Pascasarjana Universitas Sebelas Maret Surakarta.

Andi Hamzah, 1990, Pokok-Pokok Hukum Ketenagakerjaan Indonesia, Jakarta ; PT.

Rineka Cipta.

Badrudin, 2000, Pariwisata Indonesia Menuju World Class Tourism,. Jurnal Akuntansi dan Manajemen.

Budiono. (1994). Pengantar Ilmu Ekonomi Jilid I (Ekonomi Mikro). Yogyakarta: BPFE

UGM. Davey, K.J, 1998 Pembiayaan Pemerintah Daerah-Praktek-Praktek Internasional dan Relevansinya bagi Dunia Ketiga, Penerjemah Amanulah dkk, UI Press, Jakarta. 
Fandeli, Chafid. 2003. Dasar-Dasar Manajemen Kepariwisataan Alam. Yogyakarta: Liberti.

Goeldner R, Ritchie B.R.J; McIntosh W.R. 2000, Tourism :Principles, Practices, Philosophies. Jon Willey \& Sons, Canada.

Gamal Suwantoro. 1997. Dasar-Dasar Pariwisata. Yogyakarta: Andi.

Musanef. 1996. Manajemen Usaha Pariwisata Indonesia. Jakarta: PT Toko Gunung Agung

Milkovich 1994. Human Resource Management. Seventh Edition. United States of America: Irwin.

Marpaung. 2002. Pengetahuan Kepariwisataan Edisi Revisi. Bandung : Alfabeta.

Miarso. 2007. Menyemai Benih Teknologi Pendidikan. Jakarta: Pustekom Diknas.
Pendit, I Nyoman, S. 1994. Ilmu Pariwisata Sebuah Pengantar Perdana. Jakarta: Pradnya Paramita.

Pendit. 1999. Ilmu Pariwisata. Jakarta: Akademi Pariwisata Trisakti.

Pitana. I Gede. Dan Gayatri. P.G. 2015. Sosiologi Pariwisata. Yogyakarta: Penerbit Andi.

Suwantoro, G. 2004. Dasar-Dasar Pariwisata. Yogyakarta: Andi.

Sujali, 2000. Geografi Pariwisata Dan Kepariwisataan. Yogyakarta: Fakultas Geografi Univeresitas Gadjah Mada.

Suwena, I.K \& Widyatmaja, G.N. 2010. Pengetahuan Dasar Ilmu Pariwisata. Denpasar-Bali: Udayana University. 
